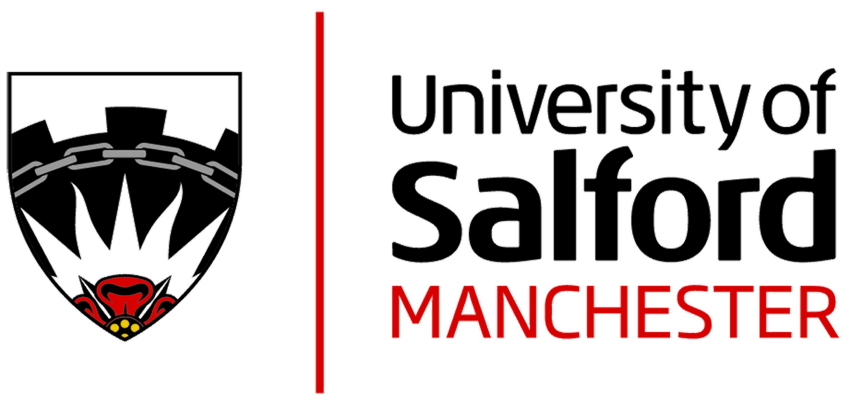

\title{
Differential Release of Sewage Sludge Biochar-borne Elements by Common Low-molecular-weight Organic Acids
}

Vause, Danielle, Heaney, Natalie and Lin, Chuxia

\begin{tabular}{|l|l|}
\hline Title & $\begin{array}{l}\text { Differential Release of Sewage Sludge Biochar-borne Elements by } \\
\text { Common Low-molecular-weight Organic Acids }\end{array}$ \\
\hline Authors & Vause, Danielle, Heaney, Natalie and Lin, Chuxia \\
\hline Type & Article \\
\hline URL & This version is available at: http://usir.salford.ac.uk/48283/ \\
\hline Published Date & 2018 \\
\hline
\end{tabular}

USIR is a digital collection of the research output of the University of Salford. Where copyright permits, full text material held in the repository is made freely available online and can be read, downloaded and copied for non-commercial private study or research purposes. Please check the manuscript for any further copyright restrictions.

For more information, including our policy and submission procedure, please contact the Repository Team at: $\underline{\text { usir@ } @ \text { salford.ac.uk. }}$ 
1 Differential Release of Sewage Sludge Biochar-borne Elements by Common Low-molecular2 weight Organic Acids

3 Danielle Vause, Natalie Heaney and Chuxia Lin*

4 School of Environment and Life Science, University of Salford, Greater Manchester M5 4WT

5 United Kingdom

6

7

8

$9 \quad *$ Corresponding Author: Email: C.Lin@salford.ac.uk 
21 Biochar materials originated from sewage sludge mat contain elevated levels of potentially toxic

22 elements. There was a lack of information on the mobility of biochar-borne elements, as driven by

23 low-molecular-weight organic acids (LMWOAs) contained in plant root exudates. A batch

24 experiment was conducted to examine the effects of three common LMWOAs on the release of 25 major elements and trace elements with a focus on various potentially toxic trace elements. The 26 results showed that substantial amounts of $\mathrm{Al}, \mathrm{Mn}, \mathrm{Fe}, \mathrm{K}, \mathrm{Na}$ and $\mathrm{Mg}$ were extracted from two 27 sewage sludge-derived biochar materials by the LMWOAs. A much higher release rate of potentially 28 toxic trace elements was observed in the presence of LMWOAs, as compared to reported data using 29 extractants not encountered in root exudates. The LMWOA-driven releasibility of various potentially 30 toxic trace elements was in the following decreasing order: $\mathrm{Zn}>\mathrm{Ni}>\mathrm{Pb}>\mathrm{Cu}>\mathrm{Cr}>\mathrm{Co}=\mathrm{Cd}$. 31 Other trace elements that are subject to mobilization in the presence of LMWOAs included B, Ba, In, $32 \mathrm{Li}$ and $\mathrm{Sr}$ except Ba under oxalic acid extraction. Among the three LMWOAs, oxalic acid showed a 33 generally stronger capacity to mobilize these metals. The findings obtained from this study provides 34 new information that can be used for better evaluating the phyto-availability of trace elements bound 35 to sewage sludge-originated biochar materials.

36 Keywords: Sewage sludge, trace elements, biochar, low-molecular-weight organic acids, phyto37 availability 


\section{Introduction}

43 Pyrolysis is viewed as an effective approach for the treatment of sewage sludge while simultaneously

44 generating bio-energy (Hossain et al., 2011; Agrafioti et al., 2013). The residue of sewage sludge

45 pyrolysis could also be used as biochar for various environmental applications (Yuan et al., 2015).

46 However, owing to generally elevated concentration of trace elements in the feedstock (van

47 Wesenbeeck et al., 2014), biochar materials originated from sewage sludge may be a source of trace elements to the environments (Hossain et al., 2010), which may limit its beneficial utilization given the potential environmental impacts from the release of the biochar-borne trace elements of potential toxicity. Therefore, it is important to understand the releasability of sewage sludge biochar-borne trace elements in order to evaluate the environmental risk associated with a given beneficial application. The mobility of sewage sludge biochar-borne trace elements was tested by various researchers using different extractants e.g. distilled water (Gondek et al., 2014; Gondek and Mierzwa-Hersztek, 2017), NH4NO3 (Mierzwa-Hersztek et al., 2018), dilute H2SO4 and HNO3 (Zhou et al., 2017), DTPA-CaCl2-TEA (Liu et al., 2014; Lu et al., 2016; Huang et al., 2017). Liu et al (2014) found sewage sludge biochar had an elevated level of total $\mathrm{Cd}, \mathrm{Cr}, \mathrm{Cu}, \mathrm{Pb}$ and $\mathrm{Zn}$ but only a small fraction of these metals was available for plant uptake and their bioavailability was in the

58 following decreasing order: $\mathrm{Zn}>\mathrm{Cr}>\mathrm{Cu}>\mathrm{Pb}>\mathrm{Cd}$. Similarly, Gondek and Mierzwa-Hersztek study by Agrafiotiet al. (2013) revealed that leachate from sewage sludge biochar contained $<0.74$ $\mathrm{mg} / \mathrm{kg}$ of heavy metals.

Soil application represents a major avenue for biochar utilization (Ahmad et al., 2014). In the rhizosphere, various low-molecular-weight organic acids (LMWOAs) are present due to root exudation (Jones and Darrah, 1994). Therefore, the added biochar materials are likely to be exposed to these naturally occurring LMWOAs, which may cause liberation of the biochar-borne elements 
through acidification, reduction or/and complexation (Onireti and Lin, 2016; Alozie et al., 2018).

While mobilization of trace elements from sewage sludge biochar materials has been investigated using chemical reagents that are not encountered in rhizosphere as mentioned above, there is currently no information on the chemical behaviour of sewage sludge biochar-borne elements in the presence of LMWOAs that are frequently encountered in rhizospheric soils. This represents a

71 knowledge gap for understanding the phyto-availability of sewage sludge biochar-borne elements in the soils amended with sewage sludge biochar materials. In this short communication, we report the observed release of various elements from two selected sewage sludge-originated biochar materials produced using the same feedstock but at different pyrolysis temperatures in the presence of three common root-released LMWOAs (citric acid, oxalic acid and malic acid). The objective was to gain plant uptake of sewage sludge biochar-borne elements.

\section{$2 \quad$ Materials and Methods}

The two sewage sludge biochar materials (labelled as SS550 and SS700 for that produced under lowoxygen conditions at a pyrolysis temperature of $550{ }^{\circ} \mathrm{C}$ and $700{ }^{\circ} \mathrm{C}$, respectively) used in the experiment were purchased from the United Kingdom Biochar Research Centre (UKBRC). The basic physical and chemical characteristics of the biochar materials provided by the manufacturer are given in Table S1 in the Supplementary Materials. The functional groups on the biochar surfaces were identified using a Fourier transform infrared spectrometer (FTIR).

A batch experiment was conducted with one control and three treatments being set for each biochar material. For the controls, $2 \mathrm{~g}$ of the respective biochar was extracted by $20 \mathrm{~mL}$ of deionized water.

89 For the treatments, $20 \mathrm{~mL}$ of $0.02 \mathrm{M}$ citric, malic or oxalic acid solution was used, respectively. The 
91 rhizosphere (Jones and Darrah, 1994). Details on the experimental set-up are provided in Table S2 in

92 the Supplementary Materials.

93 After adding all the ingredients, the batch reactors were shaken in a rotary shaker at $150 \mathrm{rpm}$ for 1 94 hour. After shaking, the $\mathrm{pH}$ and electrical conductivity (EC) in the solution were measured using a 95 calibrated $\mathrm{pH}$ meter and an EC meter, respectively. The solution was then filtered for determination 96 of various elements using an inductively coupled plasma atomic emission spectrometer (Varian 97 720ES ICP-OES).

98 The experiment was performed in triplicate. All chemical reagents used in the experiment were of 99 analytical reagent grade. Ultrapure water $(18.2 \mathrm{M} \Omega / \mathrm{cm})$ was used throughout the entire course of the 100 experiment. One-way analysis of variance (ANOVA) and Duncan's multiple range tests were used to 101 determine the statistically significant difference between the means of the controls/treatments. 102 Values were reported as the mean \pm standard error of the mean. Different letters indicate statistical 103 significance $(\mathrm{p}<0.05)$ and where no statistical significance between treatments were identified $104(\mathrm{p}>0.05)$, no letters were reported.

105 The release rate of a biochar-borne element by each of the LMWOAs is calculated using the 106 following formula:

107 Release rate $(\%)=$ ELMWOA/Etotal $\times 100$

108 Where ELMWOA stands for the concentration of an extracted element by an LMWOA and Etotal 109 denotes the total concentration of that biochar-borne element. 


\section{Results and Discussion}

113 The spectra of the two-biochar materials used for the study are shown in Fig. 1. No major changes in

114 surface functionality for the biochar materials produced under different pyrolysis temperature were

115 observed. This suggests that the biochar materials were relatively stable at these production 116 temperatures in terms of functionality (Song et al., 2014). The broad stretch observed between 3200$1173500 \mathrm{~cm}^{-1}$ can be assigned to $-\mathrm{OH}$ stretching (Keiluweit et al., 2010) and a slight decrease in 118 intensity can be observed with increased pyrolysis temperature which is indicative of increased 119 dehydration of the biochar material (Kim et al., 2012). At around $2921 \mathrm{~cm}^{-1}$ a small vibration can be 120 observed for SS700 which is attributable to a $\mathrm{CH}$ aliphatic stretch (de Jesus et al., 2017). Another 121 stretch, which indicates the presence of a $\mathrm{C}=\mathrm{O}$ bond of amide $\mathrm{I}$ at $\sim 1617 \mathrm{~cm}-1$ (Lu et al., 2013; Fan 122 et al., 2016). The strong peak observed for both biochar at $\sim 1385 \mathrm{~cm}^{-1}$ is most likely aliphatic $\mathrm{CH}_{3}$ 123 deformation (Özçimen and Ersoy-Meriçboyu, 2010). A broad stretch present between 1000-1200 $124 \mathrm{~cm}^{-1}$ can be assigned as aliphatic ether $\mathrm{C}-\mathrm{O}$ and alcohol $\mathrm{C}-\mathrm{O}$ stretching (Özçimen and Ersoy125 Meriçboyu, 2010), which becomes more pronounced with increased pyrolysis temperature. There 126 was only a slight difference in absorbance between the pre-extraction and post-extraction FTIR 127 spectra (data not shown), indicating that no removal or formation of new functional groups on the reacted biochar materials. Scanning electron micrographs revealed a porous structure with substantial amounts of the precipitates for both biochar materials (Fig. S1). 


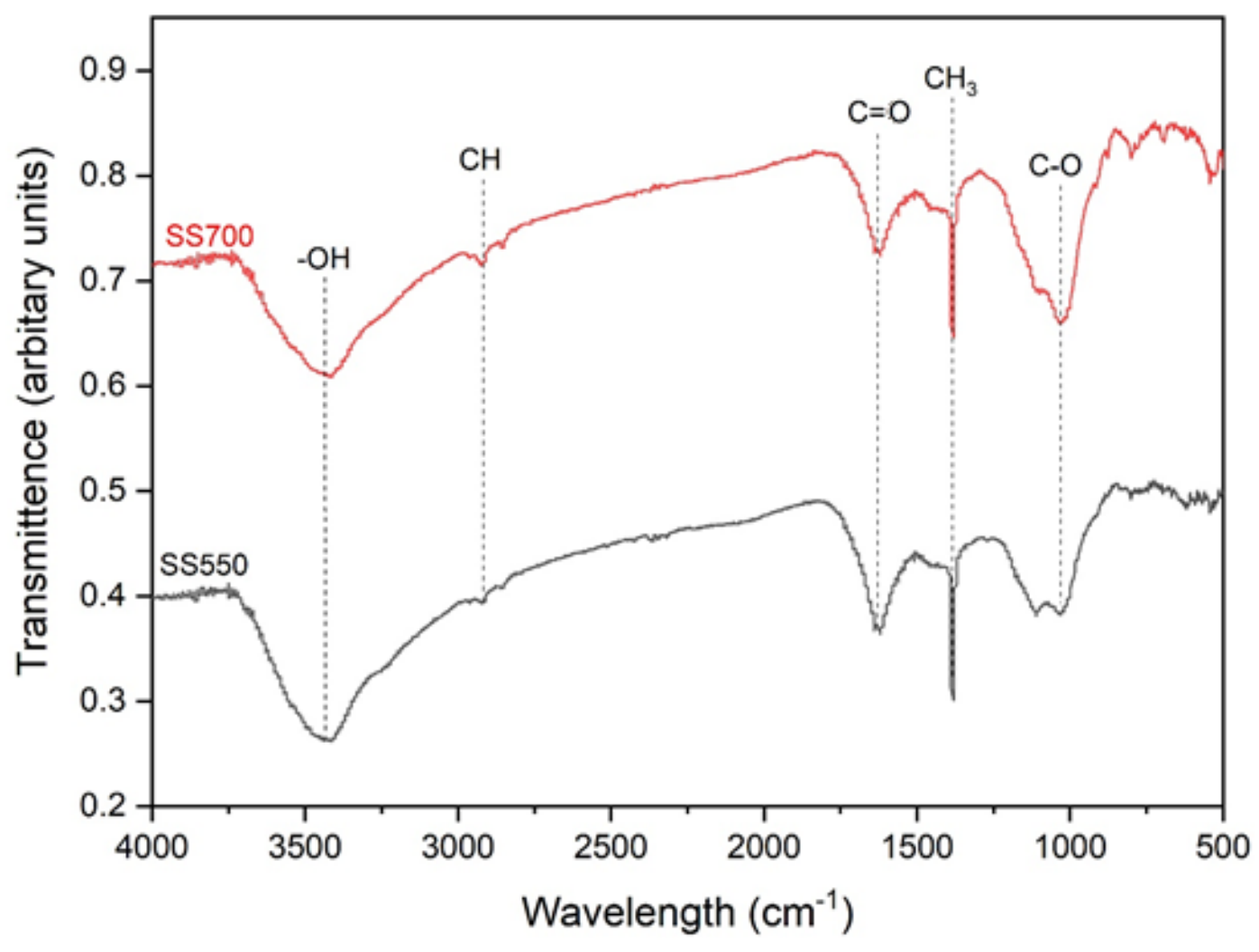

131 Figure 1 FTIR spectra of the two biochar materials (SS550 and SS700) used in the experiment.

133 After the reaction, the mean $\mathrm{pH}$ in the control for SS550 was 7.20, which was significantly $(\mathrm{P}<0.05)$ 134 lower than that $(\mathrm{pH}$ 8.87) in the control for SS700 (Table 1). This was expected because the former 135 was less alkaline, as compared to the latter (Table S1 in the Supplementary Materials). For each 136 biochar material, the mean $\mathrm{pH}$ in any LMWOA treatment was always lower than that in the 137 respective control. This was due to acidification by the added organic acids. EC in the solutions also 138 generally increased after addition of citric and malic acids (Table 1), reflecting the dissolution of the 139 biochar-borne compounds. 


\begin{tabular}{lll}
\hline Treatment & $\mathbf{p H}$ & $\mathbf{E C}(\boldsymbol{\mu S} / \mathbf{m})$ \\
\hline SS550 & $7.20 \pm 0.01 \mathrm{~b}$ & $259 \pm 1.67 \mathrm{ab}$ \\
SS700 & $8.87 \pm 0.06 \mathrm{a}$ & $185 \pm 6.84 \mathrm{~b}$ \\
SS550-C & $6.44 \pm 0.12 \mathrm{f}$ & $411 \pm 69.55 \mathrm{a}$ \\
SS550-M & $6.43 \pm 0.04 \mathrm{f}$ & $385 \pm 116.43 \mathrm{a}$ \\
SS550-O & $6.57 \pm 0.02 \mathrm{ef}$ & $258 \pm 6.00 \mathrm{ab}$ \\
SS700-C & $6.66 \pm 0.02 \mathrm{de}$ & $254 \pm 0.67 \mathrm{ab}$ \\
SS700-M & $6.77 \pm 0.03 \mathrm{~d}$ & $258 \pm 9.60 \mathrm{ab}$ \\
SS700-O & $7.02 \pm 0.02 \mathrm{c}$ & $144 \pm 1.76 \mathrm{~b}$ \\
\hline
\end{tabular}

143 Values are means \pm standard error of the mean $(n=3)$. Means in each column with different letters 144 indicate statistical significance $(\mathrm{P}<0.05)$

In both controls (SS550 and SS700), no Al was detected. For Fe, only a trace amount was detected for SS700 and none was detected for SS550. These are expected since the solubility of aluminium and iron oxides is low at neutral and slightly alkaline $\mathrm{pH}$. Significantly more $(\mathrm{P}<0.05) \mathrm{K}$ was released from SS550, as compared to SS700. For both biochar materials, oxalic acid tended to extract more Al, as compared to either citric acid or malic acid. More Al tended to be extracted from SS550, as compared to SS700 (Table 2). It is likely that the biochar-borne Al was mainly in hydrolysed 152 form. Given that the solution $\mathrm{pH}$ was above 6 , the mobilization of biochar-borne $\mathrm{Al}$ was likely to be driven by complexation rather than acidification. Under the set experimental conditions, oxalic acid is more effective in terms of solubilizing aluminium hydroxides. The same trend (oxalic acid treatment > citric acid and malic acid treatments) for Fe was observed only for SS700. For SS550, citric acid tended to extract more Fe, as compared to malic acid and oxalic acid despite that there was no statistically significant difference being observed $(\mathrm{P}>0.05)$. The concentration of $\mathrm{K}, \mathrm{Na}$ and $\mathrm{Mg}$ was all lower in the controls than in the treatments (Table 2), suggesting a release of exchangeable $\mathrm{K}, \mathrm{Na}$ and $\mathrm{Mg}$ by $\mathrm{H}^{+}$from the organic acid. At the same molar concentration, oxalic acid has a stronger $\mathrm{pK}_{\mathrm{a}}$ value as compared to the other two LMWOAs (citric acid $\mathrm{pK}_{\mathrm{a}}=3.13$, malic acid $\mathrm{pK}_{\mathrm{a}}=$ 3.46 and oxalic acid $\mathrm{pK}_{\mathrm{a}}=1.25$, respectively) (Strobel, 2001). This may partially explain why significantly more $\mathrm{K}$ and $\mathrm{Na}(\mathrm{P}<0.05)$ were extracted in the oxalic acid treatment than in the other 
organic acid treatments for SS550. Unlike other basic cations, Ca showed no significant difference between the control and the treatments (Table 2), suggesting that $\mathrm{Ca}$ in the solution was from the dissolution of water-soluble calcium compounds and no exchangeable $\mathrm{Ca}$ was released from the biochar materials. The high level of water-extractable $\mathrm{Mn}$ in the controls indicated the presence of water-soluble $\mathrm{Mn}^{2+}$, which is relatively stable in a pH less 8 (McBride, 1994). In general, the added

LMWOAs significantly enhanced the release of Mn from the biochar materials, especially for SS550 (Table 2). This may be attributed to cation exchange (replacement of exchangeable $\mathrm{Mn}$ by $\mathrm{H}^{+}$from

the added organic acids), and dissolution of manganese compounds via complexation to form soluble manganese-citrate/malate/oxalate complexes and reduction to form soluble $\mathrm{Mn}^{2+}$ (Onireti and Lin, 2016; Alozie et al., 2018).

Table 2 Comparison of extractable major elements $(\mathrm{mg} / \mathrm{kg})$ in the biochar materials among the controls and treatments

\begin{tabular}{llllllll}
\hline Treatment & $\mathbf{A l}(\mathbf{m g} / \mathbf{k g})$ & $\mathbf{C a}(\mathbf{m g} / \mathbf{k g})$ & $\mathbf{F e}(\mathbf{m g} / \mathbf{k g})$ & $\mathbf{K}(\mathbf{m g} / \mathbf{k g})$ & $\mathbf{M g}(\mathbf{m g} / \mathbf{k g})$ & $\mathbf{M n}(\mathbf{m g} / \mathbf{k g})$ & $\mathbf{N a}(\mathbf{m g} / \mathbf{k g})$ \\
\hline SS550 & $0.00 \pm 0.00 \mathrm{~d}$ & $859 \pm 3.77 \mathrm{a}$ & $0.00 \pm 0.00 \mathrm{~d}$ & $1216 \pm 63.4 \mathrm{~d}$ & $533 \pm 17.2 \mathrm{e}$ & $5.91 \pm 0.00 \mathrm{~cd}$ & $1122 \pm 138 \mathrm{c}$ \\
SS700 & $0.00 \pm 0.00 \mathrm{~d}$ & $797 \pm 2.33 \mathrm{a}$ & $3.55 \pm 3.55 \mathrm{~d}$ & $310 \pm 41.4 \mathrm{e}$ & $1623 \pm 128 \mathrm{c}$ & $0.35 \pm 0.65 \mathrm{e}$ & $276 \pm 13.1 \mathrm{e}$ \\
SS550-C & $5098 \pm 1252 \mathrm{bc}$ & $707 \pm 90.9 \mathrm{a}$ & $18165 \pm 4413 \mathrm{a}$ & $2317 \pm 601 \mathrm{ac}$ & $4043 \pm 988 \mathrm{~b}$ & $504 \pm 0.26 \mathrm{~b}$ & $1421 \pm 367 \mathrm{bc}$ \\
SS550-M & $4524 \pm 396 \mathrm{bc}$ & $806 \pm 8.00 \mathrm{a}$ & $11245 \pm 3516 \mathrm{ac}$ & $2634 \pm 14.4 \mathrm{ab}$ & $5163 \pm 703 \mathrm{~b}$ & $419 \pm 120 \mathrm{bc}$ & $1749 \pm 111 \mathrm{~b}$ \\
SS550-O & $9032 \pm 2491 \mathrm{a}$ & $823 \pm 23.8 \mathrm{a}$ & $11132 \pm 5452 \mathrm{ac}$ & $2725 \pm 227 \mathrm{a}$ & $4769 \pm 51.7 \mathrm{~b}$ & $772 \pm 45.4 \mathrm{a}$ & $2384 \pm 26.8 \mathrm{a}$ \\
SS700-C & $3641 \pm 134 \mathrm{bc}$ & $824 \pm 1.81 \mathrm{a}$ & $6636 \pm 249 \mathrm{bcd}$ & $1952 \pm 21.3 \mathrm{bcd}$ & $7483 \pm 6.33 \mathrm{a}$ & $272 \pm 71.2 \mathrm{~cd}$ & $827 \pm 24.9 \mathrm{~d}$ \\
SS700-M & $2440 \pm 49.1 \mathrm{~cd}$ & $823 \pm 2.55 \mathrm{a}$ & $3603 \pm 54.9 \mathrm{~cd}$ & $1669 \pm 45.2 \mathrm{~cd}$ & $7217 \pm 92.6 \mathrm{a}$ & $200 \pm 2.85 \mathrm{~d}$ & $914 \pm 6.01 \mathrm{~d}$ \\
SS700-O & $6561 \pm 304 \mathrm{ab}$ & $823 \pm 7.35 \mathrm{a}$ & $13420 \pm 761 \mathrm{ab}$ & $1877 \pm 80.6 \mathrm{~cd}$ & $7397 \pm 138 \mathrm{a}$ & $467 \pm 4.41 \mathrm{~b}$ & $1006 \pm 43.7 \mathrm{~cd}$
\end{tabular}

Values are means \pm standard error of the mean $(n=3)$. Means in each column with different letters indicate statistical 177 significance $(\mathrm{P}<0.05)$

For common heavy metals $(\mathrm{Cd}, \mathrm{Co}, \mathrm{Cr}, \mathrm{Cu}, \mathrm{Ni}, \mathrm{Pb}$ and $\mathrm{Zn})$ of environmental importance, none was detected in the controls for all these heavy metals. Due to the alkaline conditions, the surfaces of biochar and oxides tended to be negatively charged, which favoured the binding of cationic heavy metals but or anionic heavy metals. Therefore, it was unlikely that the biochar-borne $\mathrm{Cr}$ was in anionic forms such as $\mathrm{CrO}_{4}{ }^{2-}$ and $\mathrm{Cr}_{2} \mathrm{O}_{7}{ }^{2-}$. $\mathrm{Cd}$ and $\mathrm{Co}$ were not detected in the treatments either (data not shown). Different patterns were observed for $\mathrm{Cr}, \mathrm{Cu}, \mathrm{Ni}, \mathrm{Pb}$ and $\mathrm{Zn}$ (Fig. 2). Addition of 
185 LMWOAs tended to result in the release of $\mathrm{Cr}$ from the biochar materials though the citric acid 186 treatment was more effective, especially for SS550. Gabriel and Salifoglou (2005) found that $\mathrm{Cr}$ 187 could favourably form a soluble complex with citrate. For $\mathrm{Cu}$, nothing was detected for any of 188 LMWOA treatments for SS550. For SS700, the amount of Cu released from the biochar was in the 189 following decreasing order: citric acid $>$ malic acid $>$ oxalic acid (significant at $\mathrm{P}<0.05$ ). Biochar 190 contains dissolved organic compounds, which increase with decreasing pyrolysis temperature (Smith 191 et al., 2016). Perhaps, the relatively abundant presence of biochar-borne dissolved organic 192 compounds in SS550 was responsible for the immobilization of $\mathrm{Cu}$, which has a strong affinity to 193 organic matter. The amount of Ni released was greater for SS700 than for SS550, which had no 194 detected $\mathrm{Ni}$ for the oxalic acid treatment and only a trace amount of extracted Ni for the malic and 195 citric acid treatments. The amount of extracted Ni from SS700 was smaller (significant at P <0.05) 196 in the malic acid treatment than in the other two treatments. The extracted $\mathrm{Pb}$ tended to decrease 197 from citric acid treatment to malic acid treatment to oxalic acid treatment for both biochar materials 198 though not all of them are statistically significant. Zn was the most abundant heavy metal released 199 from the biochar materials in this experiment. The amount of extracted Zn was significantly (P $200<0.05)$ greater in the oxalic acid treatment than the other two organic acid treatments for both biochar 201 materials (Fig. 2b). 


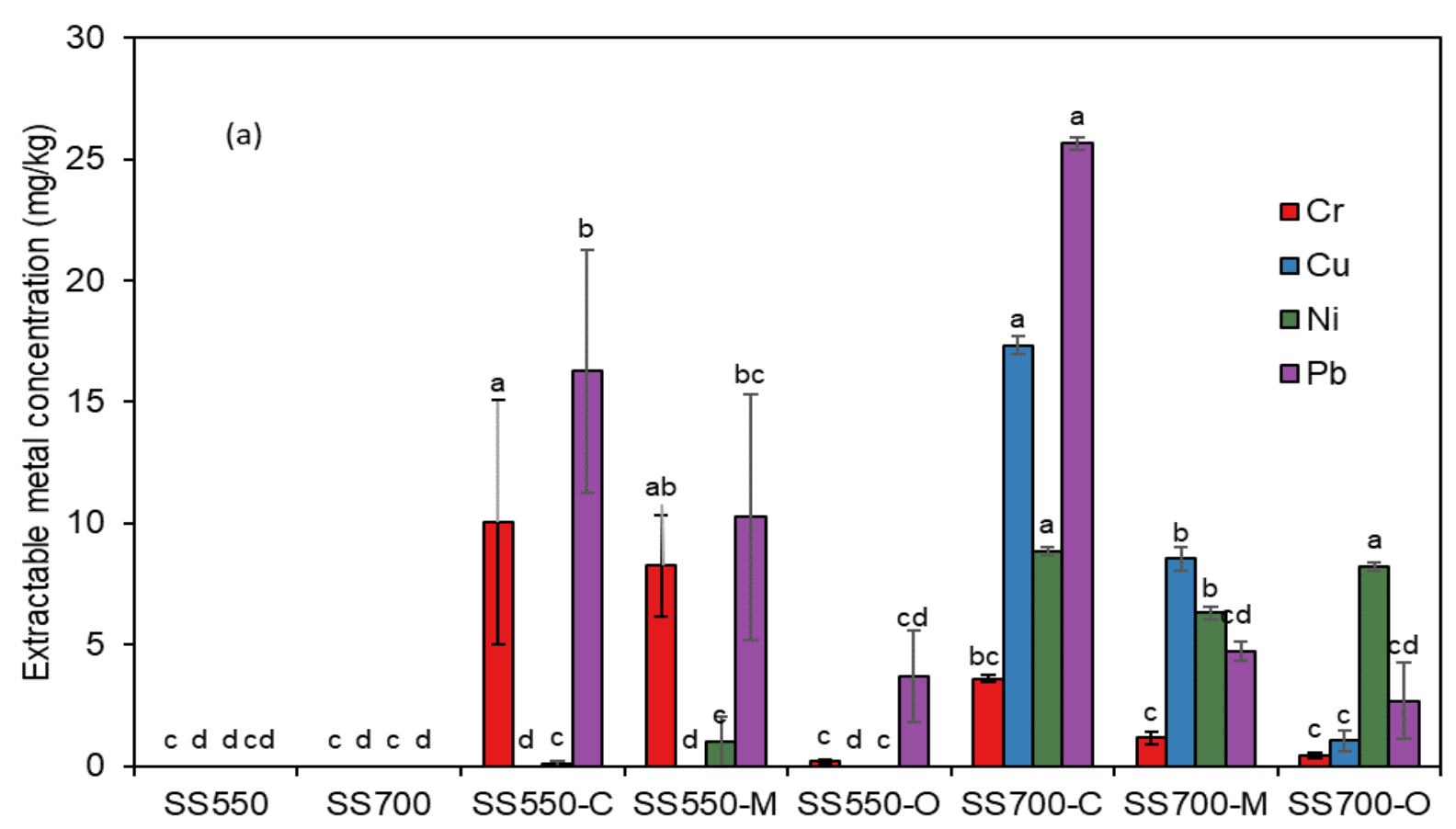

202

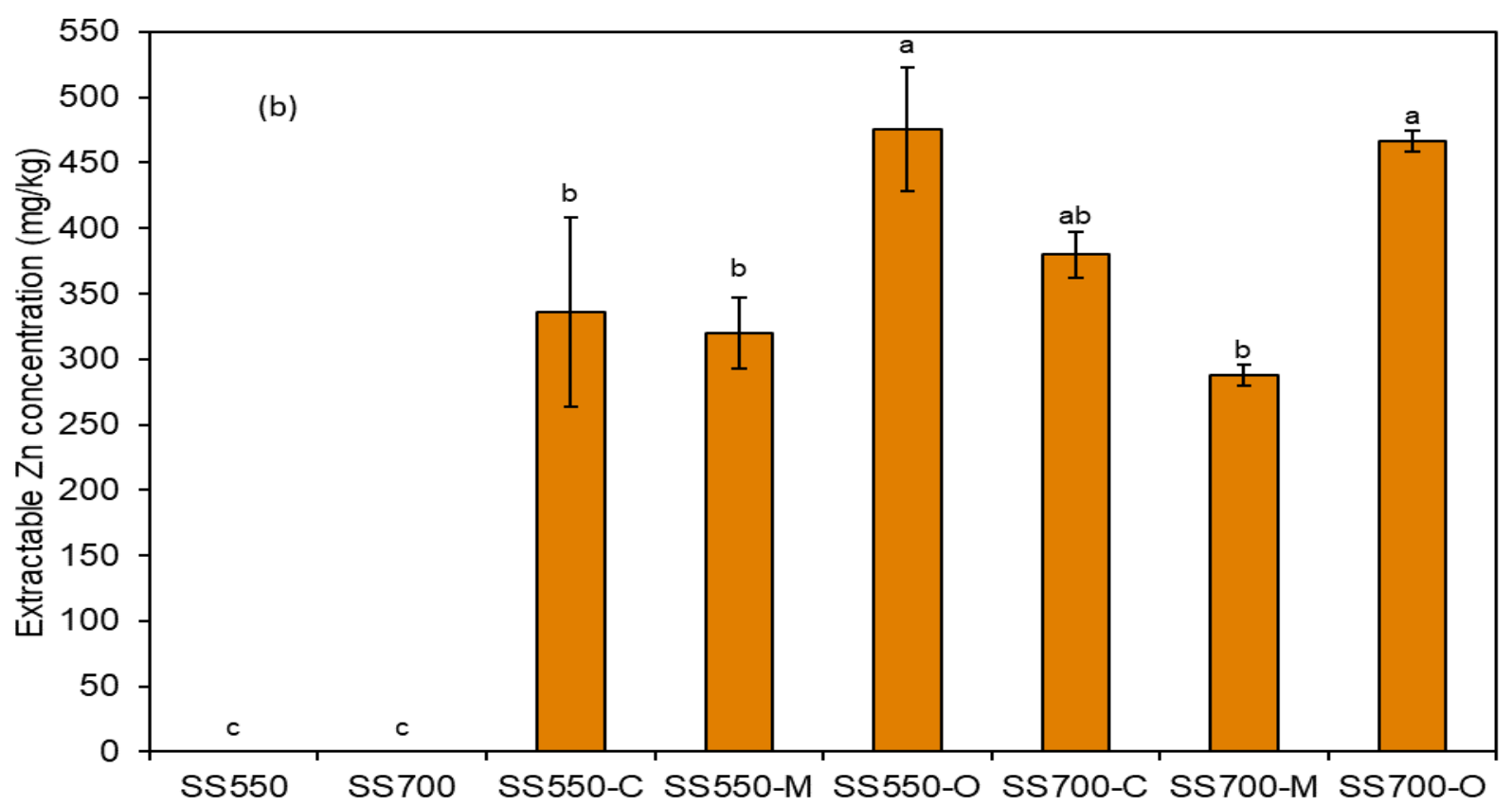

Figure 2 Comparison of extractable (a) $\mathrm{Cr}, \mathrm{Cu}, \mathrm{Ni}, \mathrm{Pb}$ and (b) $\mathrm{Zn}$ in the biochar materials 205 among the controls and treatments. Different letters above the bars indicate statistically

208 Liberation of several other trace elements from the biochar materials was also observed (Table 3).

209 The water- and LMWOA-extractable B tended to be higher in SS700 than in SS550. There was a 210 significant $(\mathrm{P}<0.05)$ difference in the released $\mathrm{B}$ for the SS550 citric acid treatment but no 
significant difference $(\mathrm{P}>0.05)$ for malic or oxalic acid treatments. Significantly $(\mathrm{P}<0.05)$ more $\mathrm{B}$ was released from SS700 compared to SS550 and the SS700 control to the order of citric acid > malic acid > oxalic acid. More Ba was released by citric acid and malic acid than by oxalic acid and for SS700, oxalic acid even caused immobilization of soluble Ba. This may be attributed to the formation of relatively insoluble Ba-oxalate complexes (Kravchenko et al., 2014) following the release of biochar-borne $\mathrm{Ba}$ by $\mathrm{H}^{+}$through cation exchange. Such complexes can precipitate, leading to the rapid removal of the extracted Ba from the solution (Strathmann and Myneni, 2004). Although no water-extractable In was presence for both biochar materials, relatively large amount of In was

extracted by the LMWOAs for SS550 and SS700 with oxalic acid showing significantly stronger (P $<0.05)$ capacity to extract In, as compared to the other two organic acids. Water extractable Li was present in both controls (SS550 > SS700) and a significant increase in concentration existed for oxalic acid treatments only $(\mathrm{P}>0.05)$. However, for SS700 nearly ten times more Li was extracted by oxalic acid (significant at $\mathrm{P}<0.05$ ). Similarly, high amounts of $\mathrm{Li}$ were also extracted for the remaining LMWOA treatments. The presence of LMWOAs led to a further release of Li, probably through cation exchange. Extractable $\mathrm{Sr}$ was detected in the control for both biochar materials. The presence of LMWOAs led to significant $(\mathrm{P}<0.05)$ release of $\mathrm{Sr}$ from the biochar materials with more Sr being released from SS500 than from SS700.

Table 3 Comparison of extractable boron, barium, indium, lithium and strontium in the biochar materials among the controls and treatments

\begin{tabular}{llllll}
\hline Treatment & B & Ba & In & Li & Sr \\
\hline SS550 & $0.07 \pm 0.07 \mathrm{~d}$ & $2.56 \pm 0.05 \mathrm{~d}$ & $0.00 \pm 0.00 \mathrm{e}$ & $4.16 \pm 0.15 \mathrm{c}$ & $14.1 \pm 0.17 \mathrm{c}$ \\
SS700 & $5.11 \pm 0.89 \mathrm{~cd}$ & $0.27 \pm 0.06 \mathrm{~cd}$ & $0.00 \pm 0.00 \mathrm{de}$ & $1.92 \pm 0.07 \mathrm{e}$ & $4.11 \pm 0.19 \mathrm{~d}$ \\
SS550-C & $6.40 \pm 3.20 \mathrm{c}$ & $170 \pm 40.9 \mathrm{c}$ & $15.7 \pm 5.33 \mathrm{~b}$ & $6.55 \pm 1.58 \mathrm{c}$ & $87.3 \pm 20.5 \mathrm{a}$ \\
SS500-M & $2.73 \pm 0.32 \mathrm{~cd}$ & $152 \pm 16.8 \mathrm{~cd}$ & $12.2 \pm 1.87 \mathrm{bc}$ & $7.34 \pm 0.18 \mathrm{bc}$ & $88.9 \pm 1.60 \mathrm{a}$ \\
SS550-O & $5.15 \pm 1.00 \mathrm{~cd}$ & $0.00 \pm 0.00 \mathrm{~cd}$ & $26.2 \pm 2.52 \mathrm{a}$ & $11.0 \pm 0.05 \mathrm{a}$ & $51.5 \pm 23.1 \mathrm{~b}$ \\
SS700-C & $29.5 \pm 0.97 \mathrm{a}$ & $88.1 \pm 1.39 \mathrm{a}$ & $7.00 \pm 0.18 \mathrm{~cd}$ & $8.58 \pm 0.11 \mathrm{~b}$ & $54.2 \pm 0.24 \mathrm{~b}$ \\
SS700-M & $24.64 \pm 1.66 \mathrm{ab}$ & $66.62 \pm 2.42 \mathrm{ab}$ & $3.07 \pm 0.15 \mathrm{de}$ & $7.39 \pm 0.16 \mathrm{bc}$ & $45.17 \pm 0.96 \mathrm{bc}$ \\
SS700-O & $22.51 \pm 3.11 \mathrm{~b}$ & $0.00 \pm 0.00 \mathrm{~b}$ & $14.67 \pm 0.80 \mathrm{~b}$ & $10.50 \pm 0.55 \mathrm{a}$ & $25.08 \pm 2.86 \mathrm{bd}$ \\
\hline
\end{tabular}

230 Values are means \pm standard error of the mean $(n=3)$. Means in each column with different letters 231 indicate statistical significance $(\mathrm{P}<0.05)$ 
233 The release rate $(\%)$ of $\mathrm{Cd}, \mathrm{Co}, \mathrm{Cr}, \mathrm{Cu}, \mathrm{Ni}, \mathrm{Pb}$ and $\mathrm{Zn}$ for the two biochar materials tested in this 234 study can be seen from Fig. 3. The releasibility of Zn was evident with over $30 \%$ of the biochar235 borne $\mathrm{Zn}$ being liberated and oxalic acid tending to mobilize more $\mathrm{Zn}$. The release rate of the 236 biochar-borne elements by the LMWOAs generally followed the order $\mathrm{Zn}>\mathrm{Ni}>\mathrm{Pb}>\mathrm{Cu}>\mathrm{Cr}>\mathrm{Co}$ $237=\mathrm{Cd}$. While the high mobility of $\mathrm{Zn}$ observed in this study was comparable to what were reported by 238 other authors using other extracting agents, the LMWOA-driven release rate of trace elements was 239 much higher and the order of mobility for various trace elements was also different, as compared to 240 their reported rate (Liu et al., 2014; Gondek and Mierzwa-Hersztek, 2017).

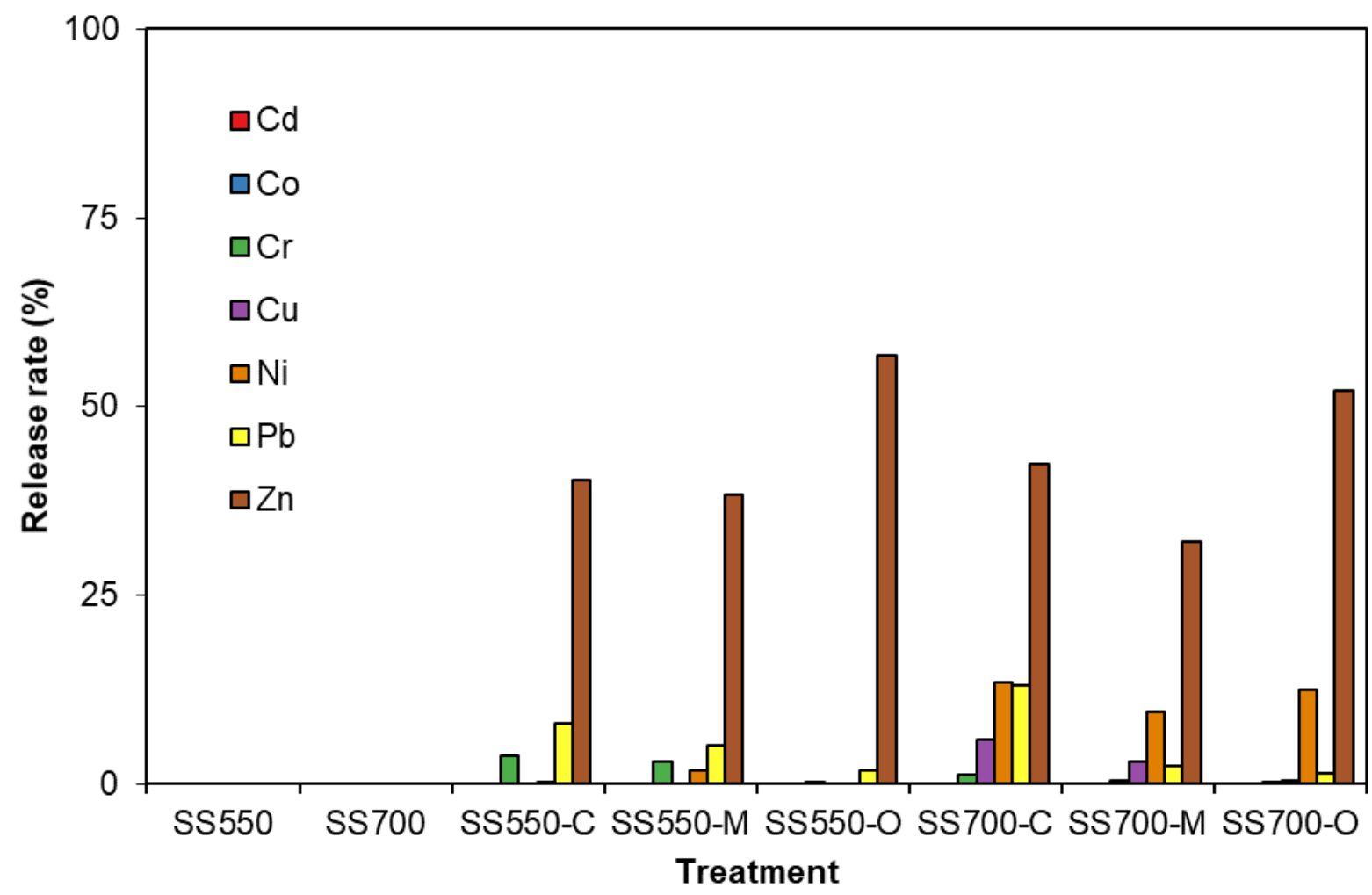

Figure 3 Release rate (\%) of biochar-borne $\mathrm{Cd}, \mathrm{Co}, \mathrm{Cr}, \mathrm{Cu}, \mathrm{Ni}, \mathrm{Pb}$ and $\mathrm{Zn}$ among the controls 244

Since extraction of biochar-borne trace elements by LMWOAs better simulates the soil conditions in the rhizosphere, the findings from this study provide new information that can be used for better evaluating the phyto-availability of trace elements bound to sewage sludge biochar materials. 
250 Substantial amounts of $\mathrm{Al}, \mathrm{Mn}, \mathrm{Fe}, \mathrm{K}, \mathrm{Na}$ and $\mathrm{Mg}$ could be released from the sewage sludge biochar 251 materials in the presence of LMWOAs through dissolution and cation exchange with oxalic acid 252 showing a generally stronger capacity to mobilize these metals. There was a much higher release rate 253 of potentially toxic trace elements in the presence of LMWOAs, as compared to that mobilized by 254 chemical substances not encountered in root exudates. The LMWOA-driven releasibility of various 255 potentially toxic trace elements was in the following decreasing order: $\mathrm{Zn}>\mathrm{Ni}>\mathrm{Pb}>\mathrm{Cu}>\mathrm{Cr}>\mathrm{Co}$ $256=\mathrm{Cd}$. Other trace elements that are subject to mobilization in the presence of LMWOAs included B, $257 \mathrm{Ba}, \mathrm{In}, \mathrm{Li}$ and $\mathrm{Sr}$ except for Ba under oxalic acid extraction.

\section{References}

Agrafioti, E., Bouras, G., Kalderis, D., \& Diamadopoulos, E. (2013). Biochar production by sewage sludge pyrolysis. Journal of Analytical and Applied Pyrolysis, 101, 72-78.

Ahmad, M., Rajapaksha, A. U., Lim, J. E., Zhang, M., Bolan, N., Mohan, D., ... \& Ok, Y. S. (2014). Biochar as a sorbent for contaminant management in soil and water: a review. Chemosphere, 99, 19-33.

Alozie, N., Heaney, N., \& Lin, C. (2018). Biochar immobilizes soil-borne arsenic but not cationic metals in the presence of low-molecular-weight organic acids. Science of the Total Environment, 630, 1188-1194.

de Jesus, J. H. F., Cunha, G. D. C., Cardoso, E. M. C., Mangrich, A. S., \& Romão, L. P. C. (2017). Evaluation of waste biomasses and their biochars for removal of polycyclic aromatic hydrocarbons. Journal of Environmental Management, 200, 186-195.

Fan, S., Tang, J., Wang, Y., Li, H., Zhang, H., Tang, J., ... \& Li, X. (2016). Biochar prepared from co-pyrolysis of municipal sewage sludge and tea waste for the adsorption of methylene blue from aqueous solutions: kinetics, isotherm, thermodynamic and mechanism. Journal of Molecular Liquids, 220, 432-441.

Gabriel, K. \& Salifoglou, A. (2005). A Chromium-citrate complex from aqueous solutions. Agroalimentary Processes and Technologies, XI(1), 57-60. 
Gondek K., Baran A., Kopeć M. 2014. The effect of low-temperature transformation of mixtures of sewage sludge and plant materiale on content, leachability and toxicity of heavy metals. Chemosphere, 117, 33-39.

Gondek, K., \& Mierzwa-Hersztek, M. (2017). Effect of thermal conversion of municipal sewage sludge on the content of $\mathrm{Cu}, \mathrm{Cd}, \mathrm{Pb}$ and $\mathrm{Zn}$ and phytotoxicity of biochars. Journal of Elementology, 22(2), 427-435.

Hossain, M. K., Strezov, V., Chan, K. Y., \& Nelson, P. F. (2010). Agronomic properties of wastewater sludge biochar and bioavailability of metals in production of cherry tomato (Lycopersicon esculentum). Chemosphere, 78(9), 1167-1171.

Hossain, Mustafa \& Strezov, Vladimir \& Yin Chan, K \& Ziolkowski, Artur \& Nelson, Peter. (2011). Influence of pyrolysis temperature on production and nutrient properties of wastewater sludge biochar. Journal of Environmental Management, 92, 223-228.

Huang Z, Lu Q, Wang J, Chen X, Mao X, He Z (2017) Inhibition of the bioavailability of heavy metals in sewage sludge biochar by adding two stabilizers. PLoS ONE, 12(8), e0183617. https://doi.org/10.1371/journal.pone.0183617

Huang, H. J., Yang, T., Lai, F. Y., \& Wu, G. Q. (2017). Co-pyrolysis of sewage sludge and sawdust/rice straw for the production of biochar. Journal of Analytical and Applied Pyrolysis, 125, 61-68.

Jones, D. L., \& Darrah, P. R. (1994). Role of root derived organic acids in the mobilization of nutrients from the rhizosphere. Plant and soil, 166(2), 247-257.

Keiluweit, M., Nico, P. S., Johnson, M. G., \& Kleber, M. (2010). Dynamic molecular structure of plant biomass-derived black carbon (biochar). Environmental Science \& Technology, 44(4), 1247-1253.

Kim, K. H., Kim, J. Y., Cho, T. S., \& Choi, J. W. (2012). Influence of pyrolysis temperature on physicochemical properties of biochar obtained from the fast pyrolysis of pitch pine (Pinus rigida). Bioresource Technology, 118, 158-162.

Kravchenko, J., Darrah, T. H., Miller, R. K., Lyerly, H. K., \& Vengosh, A. (2014). A review of the health impacts of barium from natural and anthropogenic exposure. Environmental Geochemistry and Health, 36(4), 797-814.

Liu T., Liu B., Zhang W. (2014) Nutrients and Heavy Metals in Biochar Produced by Sewage Sludge Pyrolysis: Its Application in Soil Amendment. Pol. J. Environ. Stud., 23(1): 271-275

Lu, H., Zhang, W., Wang, S., Zhuang, L., Yang, Y., \& Qiu, R. (2013). Characterization of sewage sludge-derived biochars from different feedstocks and pyrolysis temperatures. Journal of Analytical and Applied Pyrolysis, 102, 137-143.

Lu, T., Yuan, H., Wang, Y., Huang, H., \& Chen, Y. (2016). Characteristic of heavy metals in biochar derived from sewage sludge. Journal of Material Cycles and Waste Management, 18(4), 725733.

McBride, M. B., (1994) Environmental Chemistry of Soils. New York: Oxford University Press, Inc. 
Mierzwa- Hersztek, M., Gondek, K., Klimkowicz- Pawlas, A., Baran, A., \& Bajda, T. (2018). Sewage sludge biochars management-ecotoxicity, mobility of heavy metals and soil microbial biomass. Environmental Toxicology and Chemistry, 37(4):1197-1207.

Onireti, O.O., Lin, C., 2016. Mobilization of soil-borne arsenic by three common organic acids: Dosage and time effects. Chemosphere, 147, 352-360.

Özçimen, D., \& Ersoy-Meriçboyu, A. (2010). Characterization of biochar and bio-oil samples obtained from carbonization of various biomass materials. Renewable Energy, 35(6), 13191324.

\section{Schwertmann, U. (1991). Solubility and dissolution of iron oxides. Plant and Soil, 130(1/2), 1-25.}

Smith, C. R., Hatcher, P. G., Kumar, S. \& Lee, J. W. (2016). Investigation into the sources of biochar water-soluble organic compounds and their potential toxicity on aquatic microorganisms. ACS Sustainable Chemistry \& Engineering, 4(5), 2550-2558.

Song, X. D., Xue, X. Y., Chen, D. Z., He, P. J., \& Dai, X. H. (2014). Application of biochar from sewage sludge to plant cultivation: Influence of pyrolysis temperature and biochar-to-soil ratio on yield and heavy metal accumulation. Chemosphere, 109, 213-220.

Strathmann, T. J., \& Myneni, S. C. (2004). Speciation of aqueous Ni (II)-carboxylate and Ni (II)fulvic acid solutions: Combined ATR-FTIR and XAFS analysis 1. Geochimica et Cosmochimica Acta, 68(17), 3441-3458.

Strobel, B. W. (2001). Influence of vegetation on low-molecular-weight carboxylic acids in soil solution-a review. Geoderma, 99(3-4), 169-198.

Van Wesenbeeck, S., Prins, W., Ronsse, F., \& Antal Jr, M. J. (2014). Sewage sludge carbonization for biochar applications. Fate of heavy metals. Energy \& Fuels, 28(8), 5318-5326.

Yuan, H., Lu, T., Huang, H., Zhao, D., Kobayashi, N., \& Chen, Y. (2015). Influence of pyrolysis temperature on physical and chemical properties of biochar made from sewage sludge. Journal of Analytical and Applied Pyrolysis, 112, 284-289.

Zhou, D., Liu, D., Gao, F., Li, M., \& Luo, X. (2017). Effects of biochar-derived sewage sludge on heavy metal adsorption and immobilization in soils. International Journal of Environmental Research and Public Health, 14(7), 681. 


\section{Supplementary Materials}

Table S1 Basic characteristics of the two biochar materials used in the experiment

\begin{tabular}{lcc}
\hline Property & SS550 & SS5700 \\
\hline Moisture $(\%)$ & 2.48 & 1.69 \\
Ctot $(\%)$ & 29.53 & 29.55 \\
$\mathrm{H}(\%)$ & 1.33 & 0.83 \\
$\mathrm{O}(\%)$ & 6.5 & 2.75 \\
$\mathrm{H}: \mathrm{C}$ & 0.54 & 0.34 \\
O:C & 0.17 & 0.07 \\
Total Ash $(\%)$ & 58.89 & 63.91 \\
Total N $(\%)$ & 3.75 & 3.79 \\
$\mathrm{pH}$ & 8.29 & 9.12 \\
Electrical Conductivity (dS/m) & 0.280 & 0.113 \\
PAH (mg/kg) & 3.76 & 1.4 \\
As $(\mathrm{mg} / \mathrm{kg})$ & $<0.72$ & $<0.72$ \\
$\mathrm{Cd}(\mathrm{mg} / \mathrm{kg})$ & 11.69 & 12.36 \\
$\mathrm{Cr}(\mathrm{mg} / \mathrm{kg})$ & 275.69 & 292.72 \\
$\mathrm{Co}(\mathrm{mg} / \mathrm{kg})$ & 11.58 & 12.68 \\
$\mathrm{Cu}(\mathrm{mg} / \mathrm{kg})$ & 255.22 & 296.63 \\
$\mathrm{~Pb}(\mathrm{mg} / \mathrm{kg})$ & 201.19 & 195.97 \\
$\mathrm{Hg}(\mathrm{mg} / \mathrm{kg})$ & $<0.23$ & $<0.23$ \\
$\mathrm{Mo}(\mathrm{mg} / \mathrm{kg})$ & 5.59 & 4.67 \\
$\mathrm{Ni}(\mathrm{mg} / \mathrm{kg})$ & 57.19 & 66.25 \\
$\mathrm{Se}(\mathrm{mg} / \mathrm{kg})$ & $<1.40$ & $<1.4$ \\
$\mathrm{Zn}(\mathrm{mg} / \mathrm{kg})$ & 835.69 & 896.21 \\
Polarity Index $(\mathrm{O}+\mathrm{N}) / \mathrm{C}$ & 0.35 & 0.22 \\
\hline
\end{tabular}

Table S2 Details on experimental set-up

\begin{tabular}{lccccc}
\hline Treatment & $\begin{array}{c}\text { Biochar } \\
(\mathbf{g})\end{array}$ & $\begin{array}{c}\mathbf{0 . 0 2} \text { M citric acid } \\
(\mathbf{m L})\end{array}$ & $\begin{array}{c}\mathbf{0 . 0 2} \text { M malic acid } \\
(\mathbf{m L})\end{array}$ & $\begin{array}{c}\mathbf{0 . 0 2} \text { M oxalic acid } \\
(\mathbf{m L})\end{array}$ & $\begin{array}{c}\text { Deionized Water } \\
(\mathbf{m L})\end{array}$ \\
\hline SS550-C & 2 & 0 & 0 & 0 & 20 \\
SS700-C & 2 & 0 & 0 & 0 & 20 \\
SS550-CA & 2 & 20 & 0 & 0 & 0 \\
SS550-MA & 2 & 0 & 20 & 0 & 0 \\
SS550-OX & 2 & 0 & 0 & 20 & 0 \\
SS700-CA & 2 & 20 & 0 & 0 & 0 \\
SS700-MA & 2 & 0 & 20 & 0 & 0 \\
SS700-OX & 2 & 0 & 0 & 20 & 0 \\
\hline
\end{tabular}


Figure S1 Scanning Electron Micrograph of (a) SS550 and (b) SS700

(a)

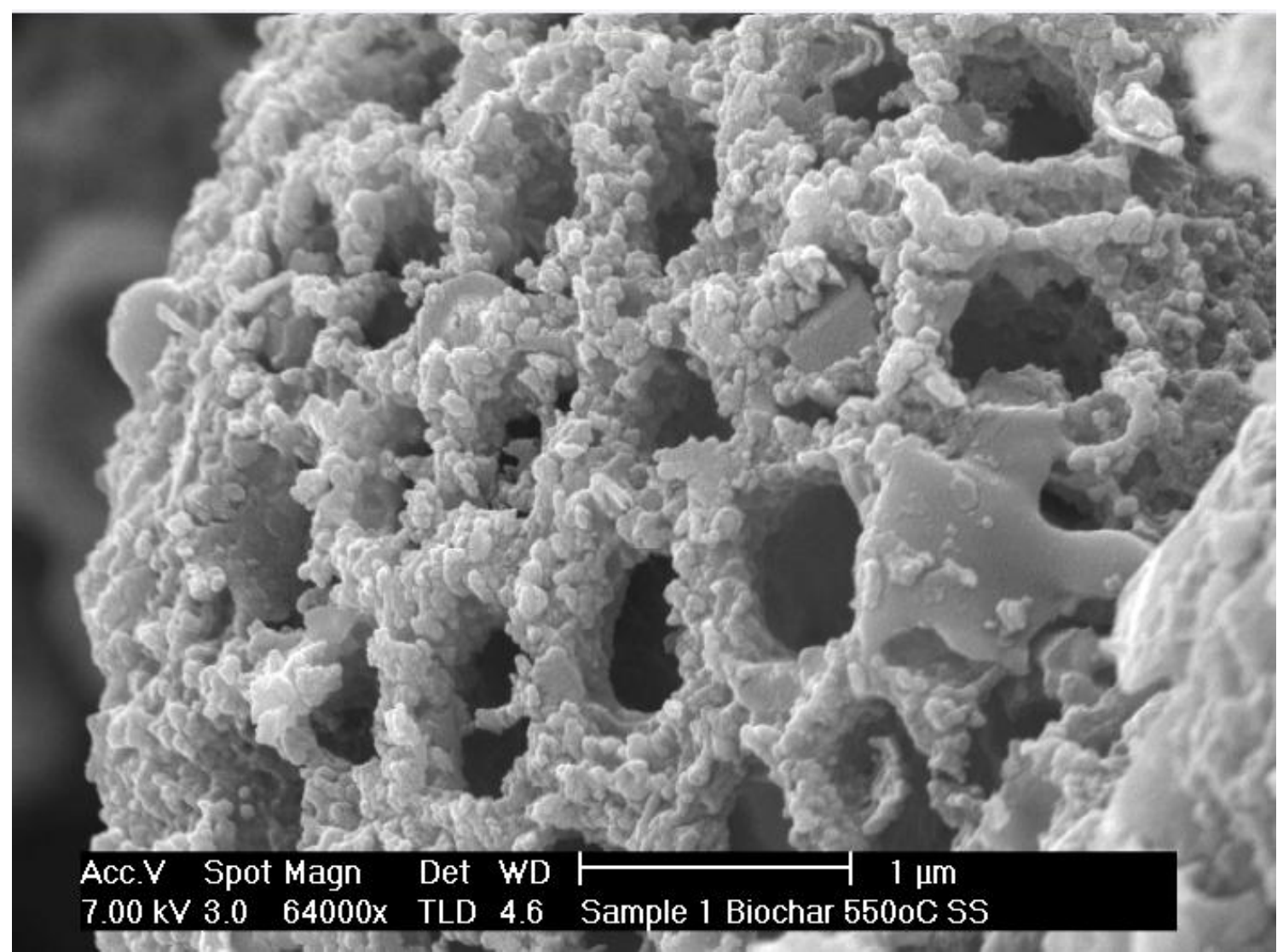

(b)

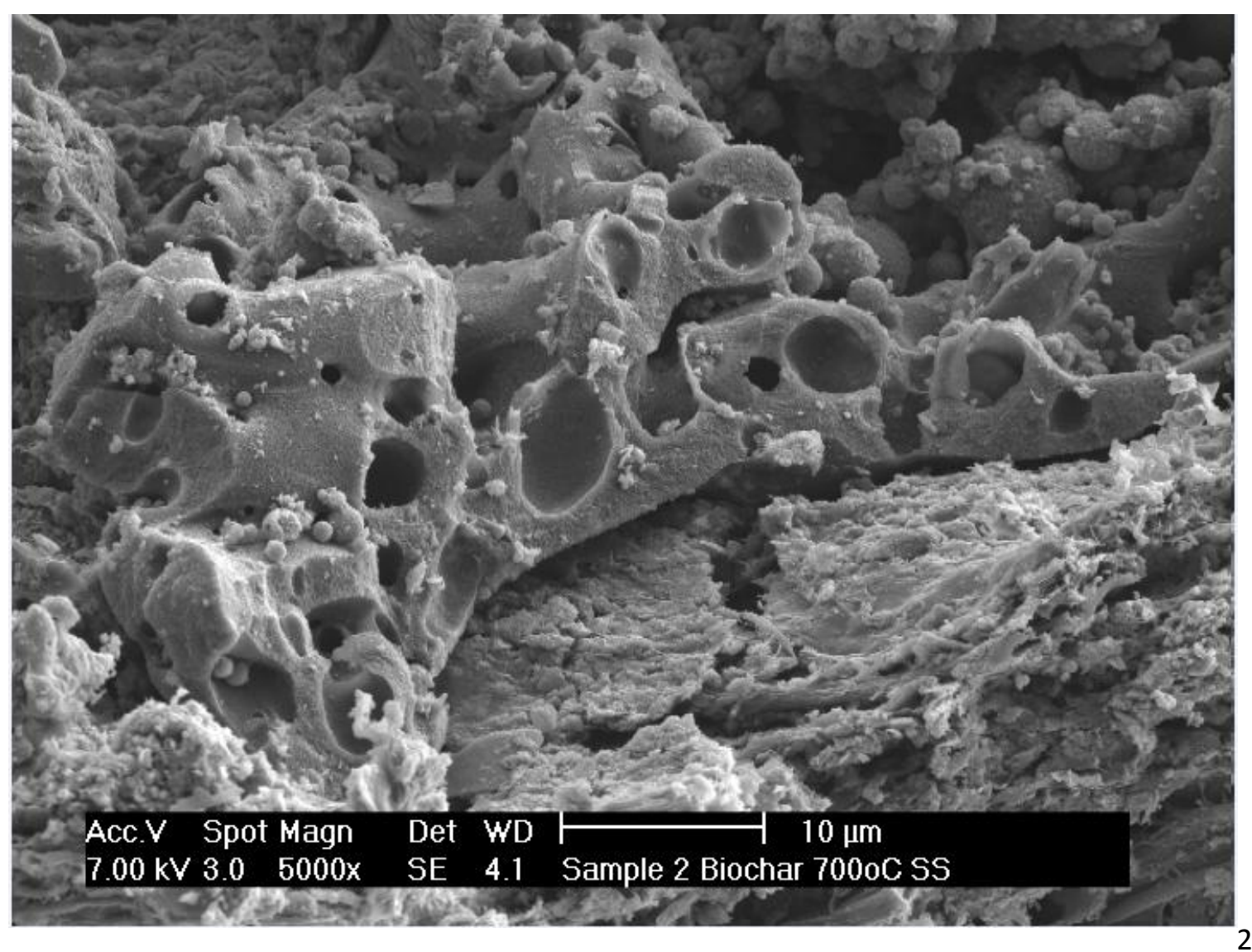

